\title{
PERFORATION OF MECKEL'S DIVERTICULUM
}

\section{BY FOREIGN BODIES}

\author{
R. P. Rosswick, M.B., M.S.(Illinois), F.R.C.S. \\ St. George's Hospital, S.W.1.
}

THE PERSISTENCE of a part of the vitello-intestinal duct as a solitary diverticulum of the ileum was was described by Ruysch in 1701, but is eponymously linked with the name of Johann Frederick Meckel, who in 1812 first described it accurately.

Many complications of surgical importance due to the presence of a Meckel's diverticulum have been described and commented on; one which has received comparatively little attention, perhaps owing to its rarity, is that of perforation by a foreign body.

The purpose of this report is to record a further case of this occurrence, and to present a bibliography of the other 49 cases which can be found in the world literature.

\section{Case Report}

Mrs. E.T., a married woman, aged 28, was admitted complaining of pain in the right iliac fossa for the previous 13 hours, which was increasing in severity. The pain was constant and had not radiated. She had not vomited and had no bowel disturbance. Micturition was normal, as was her menstrual history.

On examination: T. $98.6^{\circ}$ F, P. 88, B.P. $120 / 80$ $\mathrm{mm}$. Hg. Her tongue was furred and there was foetor oris. Abdominal examination revealed tenderness around McBurney's point with guarding but no rigidity. Bowel sounds were normal. Rectal examination was negative. Her urine contained no albumin.

A diagnosis of acute appendicitis was made.

At operation, through a gridiron incision, a normal appendix was found. However, as a finger was passed up on the left of the ascending colon a sharp "pin-like" object was felt. This was seized with a hæmostat and found to be a "bristle". Further examination revealed a broad-based Meckel's diverticulum with a small perforation at its tip. In the lumen could be felt another "bristle", the tip of which was already beginning to perforate.

The diverticulum was excised, the appendix removed and the abdominal cavity closed with drainage of the peritoneum.

The patient made an uninterrupted recovery, receiving post-operative chemotherapy with penicillin and streptomycin.

Pathological examination (Dr. J. Scott-Wilson) revealed

1. a normal appendix.

2. a Meckel's diverticulum showing normal mucosa with a small perforation.

3. the "bristles" were fishbones.

The patient denied any particular predilection for fish, and, indeed, could not remember when she had last eaten fish.

\section{Comment}

This case follows the common pattern of previous cases in that a pre-operative diagnosis of acute appendicitis was made, only to be disproved at operation. Only when a clear history of a recently swallowed foreign body is given, is it even possible to suspect this condition; and in only two cases in the literature was such a diagnosis made (Fontaine \& Bauer (1933); Persson (1939).)

This case also follows the pattern described by Seibert (1950) and Persson (1939) in that symptoms of perforation and peritonitis were mild, although sudden and severe abdominal symptoms have been reported. Perhaps the mildness of the symptoms may be related to the fineness of the perforating object-in over half the cases a fishbone.

Meckel's diverticulum has an incidence ofô $1-2 \%$ of the population, with a ratio of three males to one female. It is perhaps surprising, therefore, that more cases of perforation have not been recorded. The previous reviews by Alhadeff (1955) and Dowse (1961) recorded a total of 30 cases, however neither mentioned any reports earlier than 1899. It is interesting to note that the cases recorded by Denunce (to whom priority belongs, and who saw the case in 1847) and Beale (1852-the first report in the English literature) were both cases in which the foreign body was a cherrystone.

The variety of foreign bodies causing perforation is at first sight extensive, but considering the wide range of foreign bodies swallowed it is perhaps surprising that more of them have not caused perforation. Fishbones caused the perforation in $55 \%$ of the reported cases. What is more surprising is that objects such as rolled tomato skins and cabbage stalks can cause perforation. In all 29 objects of animal, 15 of vegetable and five of mineral origin caused perforation.

The sex incidence was 14 female and 35 male, with six cases younger than 10 years and three older than 70 . There were only two deaths in the cases reported since 1900.

\section{Addendum}

Since the compilation of this report another case, making the fiftieth in the literature, has been reported from Australia. The patient was a twelve year old boy in whom the perforation was caused by the "bristle" of a nylon tooth-brush. 
SUMMARY OF CASES

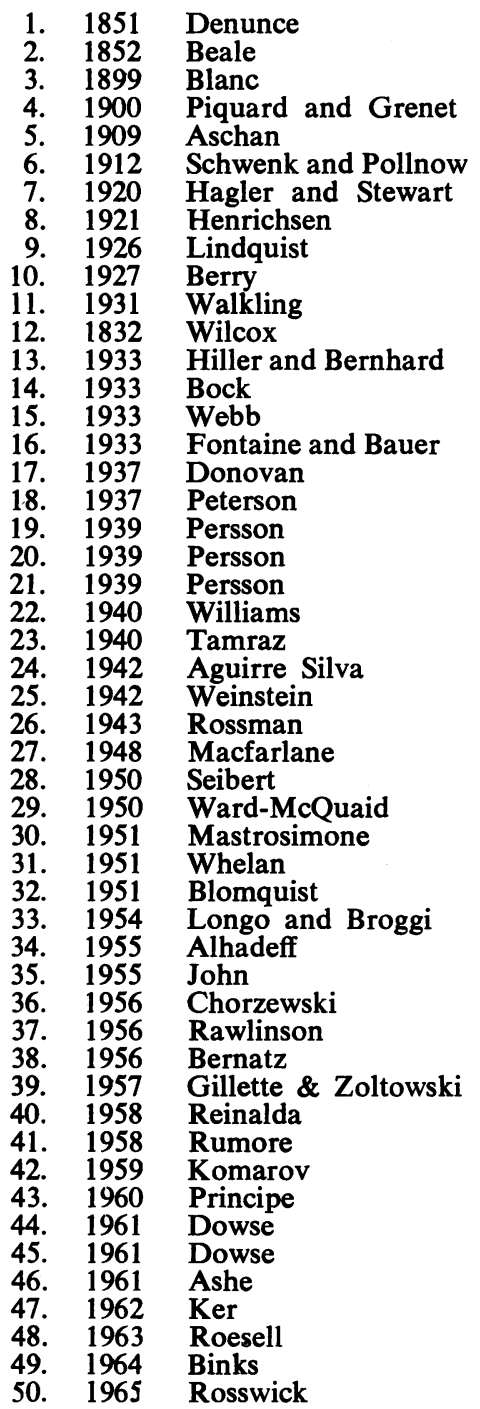

\begin{tabular}{lc} 
Male & $?$ \\
Male & 14 \\
Male & 41 \\
Female & 45 \\
Male & 42 \\
Female & 21 \\
Male & 39 \\
Male & 25 \\
Male & 21 \\
Male & 36 \\
Male & 8 \\
Male & 71 \\
Male & 41 \\
Male & 7 \\
Female & 15 \\
Female & 19 \\
Male & 11 \\
Female & 15 \\
Male & 75 \\
Male & 21 \\
Male & 18 \\
Male & 62 \\
Male & 49 \\
Male & 32 \\
Male & 54 \\
Male & 17 \\
Female & 21 \\
Male & 14 \\
Male & 60 \\
Female & 14 \\
Male & 70 \\
Female & 37 \\
Male & 32 \\
Male & 24 \\
Male & 10 \\
Female & 27 \\
Male & 57 \\
Male & 52 \\
Female & 35 \\
Female & 42 \\
Male & 41 \\
Male & 17 \\
Male & 9 \\
Female & 60 \\
Male & 9 \\
Female & 34 \\
Male & Adult \\
Male & $1 \frac{1}{2}$ \\
Male & 12 \\
Female & 28 \\
& \\
\hline
\end{tabular}

I am indebted to Mr. A. J. Walton for kind permission to publish this case and to Professor V. W. Dix for advice and encouragement.

\section{REFERENCES}

Aguirre Silva, R. (1942): Diverticulitis de Meckel Perforada or Cuerpo Extrano, Arch. Soc. Cir. Hosp., 12, 326.

AlHADEFF, R. (1955): Perforation of Meckel's Diverticulum by Foreign Body, Brit. J. Surg., 43, 555.

Aschan, T. (1909): A Case of Meckel's Diverticulum Perforated by a Foreign Body, Finska Läk.-Säelsk., Handl, 51, 118.

ASHE, P. (1961): Perforation of Meckel's Diverticulum by Foreign Body, J. Irish med. Ass., 49, 103.

Beale, L. (1852): Diverticulum from the Lower Part of the Ileum, Proc. Path. Soc. Lond., 3, 366.
Cherrystone

Cherrystone

Fishbone

Fishbone

Fishbone

Gramophone needle

Fishbone

Fishbone

Wood splinter

Wood splinter

Fishbone

Fishbone

Tomato skin

Needle

Fishbone

Knitting needle

Wood splinter

Fishbone

Fishbone

Fishbone

Wood splinter

Fishbone

Fishbone

Chicken bone

Fishbone

Fishbone

Cabbage stalk

Fishbone

Tomato skin

Ascaris

Fishbone

Fishbone

Artichoke spine

Wood splinter

Pin

Fishbone

Fishbone

Fishbone

Fishbone

Fishbone

Fishbone

Grape seeds

Prune stone

Fishbone

Tomato skin

Wood splinter

Fishbone

Liberty bell

Fishbone

Fishbone
Post-mortem, no operation Post-mortem, no operation Recovered after operation Post-mortem, no operation Recovered after operation do.

Died after operation

Recovered after operation do.

do.

do.

do.

do.

do.

do.

do.

do.

do.

do.

do.

do.

do.

do.

da.

do.

do.

do.

do.

do.

do.

do.

do.

do.

do.

do.

do.

do.

do.

do.

do.

do.

do.

do.

do.

do.

do.

do.

do.

do.

do.

Bernatz, P. E. (1956): Unusual Conditions Simulat. ing Acute Appendicitis, Proc. Mayo Clin., 31, 53

BERrY, J. A. (1927): Perforation of Meckel's Diverticulum, Brit. J. Surg., 15, 331.

BINKS, J. B. (1964): Letter in Brit. Med. J., ii, 805.

BLANC, H. H. (1899): Note Anatomo-pathologique sur les Inflammations du Diverticule de Meckel, Bull. Soc. Anat. Paris, p. 246.

BLOMQUisT, H. E. (1951): Fishbone Perforation of Meckel's Diverticulum and the Small Intestine, Nord. Med., 46, 1045.

Bock, H. (1933): Uber Meckel'sche Divertikel, $\mathrm{Zbl}$. Chir., 60, 1715.

CHORZEWSKI, Z. (1956): Rare Complication of Meckel's Diverticulum, Pol. Przegl., chir., 28, 1173. DENUNCE (1851): Bull. Soc. Anat. Paris, p. 369.

Donovan, E. J. (1937): Meckel's Diverticulum Perforated by a Foreign Body, Ann. Surg., 106, 953. 
Dowse, J. L. A. (1961): Meckel's Diverticulum, Brit. J. Surg., 48, 392.

Fontaine, R. and BaUER, R. (1933): Aiguille arretee dans une Diverticule de Meckel, Rev. Chir. (Paris), 52, 71 .

Gillette, W. R. and Zoltowski, P. E. (1957): Perforation of Meckel's Diverticulum by a Foreign Body, Amer. J. Surg., 94, 666.

HAGler, F. and STEWART, J. W. (1920): Acute Perforation of Meckel's Diverticulum by a Foreign Body (Fishbone), J. Amer. med. Ass., 74, 1377.

HENRICHSEN, A. (1921): Ueber einen Fäll von Fremkörperdivertikulitis des Meckel'schen Divertikels, Münch. med. Wschr., 68, 1423.

Hiller, R. I. and BERNHARD, L. A. (1933): Gangrenous Meckel's Diverticulum Perforated by a Tomato Peel., J. Amer. med. Ass., 101, 364.

JoHN, E. L. (1955): Perforation of Meckel's Diverticulum by a Pin, Brit. J. Surg., 43, 216.

KER, H. (1962): A Muckle of Meckel's, Lancet, i, 617.

Komarov, I. A. (1959): Perforation of Meckel's Diverticulum, Vestn. Khir., 83, 88.

LINDQUIST, S. (1926): Perforation eines Meckel'schen Divertikels, von einem Fremdkörper Bedingt, Zbl. Chir., 53, 1756.

Longo, T., and Broggi, L. (1954): Di una Singolare Complicanza di un Diverticolo di Meckel, Boll. Soc. med. chir. Varese., 9, 256.

MacFarlane, D. A. (1948): Foreign Body Perforations in Meckel's Diverticulum, Brit. J. Surg., 35, 421.

Mastrosimone, C. (1951): Perforazione del Diverticolo di Meckel ed Ascaridiasi, Arch. Att. Soc. It. Chir., 2, 359.

MeCKel, J. F. (1812): Handbuch der Pathologischen Anatomie, Vol. 1, p. 553, (Leipzig).

Persson, von T., (1939): Meckel'sches Divertikel, durch einen Fremkörper Perforiert, Acta chir. scand., 82, 530 .

Peterson, E. W. (1937): Commenting on Donovan (loc. cit.), Ann. Surg., 106, 954.
Piquand, G. and Grenet, H. (1900): Perforation d'un Diverticule Ileal par une Arete de Poisson, Bull. Soc. Anat. Paris, p. 390.

Principe, L. (1960): Perforazione da Corpo Estraneo di Diverticolo di Meckel Fibroangiomatoso, Riv. Pat. Clin., 15, 503.

Rawlinson, J. K. M. (1956): Fishbone Perforation of Meckel's Diverticulum, Brit. J. Surg., 43, 555.

Reinalda, R. (1958): A Case of Meckel's Diverticulum Perforated by a Fishbone, Geneesk. Gids., 36, 383.

RoEsSEL, C. W. (1962): Perforation of Meckel's Diverticulum by a Foreign Body; case report and review of the literature, Ann. Surg., 156, 972.

Rossman, J. I. (1943): Fishbone Perforation of Meckel's Diverticulum, Canad. med. Ass. J., 49, 48.

RUMORE, A. (1958): Perforation of Meckel's Diverticulum by Grape Seeds, Med. J. Aust., 45, 110.

RuYsCH, F. (1701): Thesaurus Anatomicus, Vol. 7, Fig. 383.

SCHWENK, C., and Pollnow, M. (1912): Fremdkörper im Meckel'schen Divertikel unter den Erscheinungen der Appendicitis, Berl. klin. Wschr., 49, 2228.

SEIBERT, F. M. (1950): Seltene Erkrankingsformd des Meckel'schen Divertikel. Fremdkörperperforation ohne Begleitdiverticulitis, Artzl. Wschr, 550, 1023.

Tamraz, J. M. (1940): Case of Acute Gangrenous Diverticulitis (Meckel's) with Perforation due to a Fishbone, Milit. Surg., 87, 328.

WALKLING, cited by Webb (q.v.).

WARD-MCQuAID, J. N. (1950): Perforated Meckel's Diverticulum by Tomato Skin, Lancet, i, 349.

WEBB, R. C. (1933): Meckel's Diverticulum Perforated by a Fishbone, Ann. Surg., 98, 159.

Weinstein, V. A. (1942): Fishbone Perforation of Meckel's Diverticulum, J. Mt. Sinai Hosp., 9, 29.

Whelan, P. J. (1951): Fishbone Perforation of Meckel's Diverticulum, Canad. med. Ass. J., 64, 67.

Wilcox, A. E. (1932): Case Report, Minn. Med., 15, 558.

Williams, R. V. (1940): Perforation of Meckel's Diverticulum by a Fishbone, Minn. Med., 23, 44.

\title{
SPONTANEOUS NECROSIS OF THE GALL BLADDER
}

\author{
J. E. Mitchell, M.B., B.Ch. (Wales), F.R.C.S. (Eng.). \\ Late Senior Surgical Registrar, The Gordon Hospital, Vauxhall Bridge Road, London, S.W.1.
}

\begin{abstract}
RUPTURE of the gall bladder is not an uncommon phenomenon usually associated with gangrene following acute calculous cholecystitis. Cases have been reported following non-calculous cholecystitis (Maingot, 1957) and there are other isolated cases of rarer causes.
\end{abstract}

\section{Case Report}

A male, aged 58, presented with a history of bleeding per rectum for six months. Routine sigmoidoscopy showed a carcinoma $11 \mathrm{~cm}$. from the anus, confirmed by histological examination.

On 7 th January, 1964 laparotomy showed a mobile carcinoma of the rectum with no obvious metastases. The gall bladder and other abdominal viscera were normal. A routine abdomino-perineal excision of the rectum was performed and his immediate recovery was satisfactory. On the ninth post-operative day pus was drained from his wound which had become inflamed and three days later he developed general peritonitis. Laparotomy showed a biliary peritonitis, there being about a pint of free bile in the abdomen. A large swelling was found in the right upper abdomen consisting of omentum wrapped round the gall bladder. On freeing the omentum, the gall bladder was found to be deeply bile stained and black at the fundus and there was a little bile 